\title{
Structural behaviour of CFRP reinforced concrete members under bending and shear loads
}

\author{
Redouan El Ghadioui (iD - Tilo Proske • Ngoc Linh Tran • Carl-Alexander Graubner
}

Received: 15 January 2020/Accepted: 15 May 2020/Published online: 9 June 2020

(C) The Author(s) 2020

\begin{abstract}
Reinforcement made of fibre-reinforced polymers (FRP) for concrete members is becoming increasingly important in structural engineering. Compared to conventional ribbed steel reinforcement bars, FRP reinforcement can be different in terms of modulus of elasticity, tensile strength and bond behaviour. This article presents and evaluates experimental investigations on the structural behaviour of concrete members under bending and shear loads. Different types of reinforcement (CFRP textile fabrics, CFRP bars, steel bars), cross-sections (slabs, beams) and types of failure (flexure, shear) are investigated. For a direct comparison with conventionally reinforced members, reference tests with steel reinforcement and comparable mechanical reinforcement ratio are carried out. The material properties and the structural behaviour of the studied concrete members are presented. The load-bearing, cracking and deformation behaviour is precisely described and the applicability of existing engineering models is checked. Additionally, the contributions to shear capacity are analysed using the deformation measurement based on digital image correlation.
\end{abstract}

R. El Ghadioui $(\bowtie) \cdot$ T. Proske · N. L. Tran .

C.-A. Graubner

Institute of Concrete and Masonry Structures, Technische

Universität Darmstadt, Franziska-Braun-Str. 3,

64287 Darmstadt, Germany

e-mail: el-ghadioui@massivbau.tu-darmstadt.de

URL: http://www.massivbau.tu-darmstadt.de
Keywords FRP · Cracking - Shear - Concrete - DIC · Size effect

\section{Introduction}

The majority of damages to existing reinforced concrete structures is caused by the corrosion of the reinforcement steel [1]. To prevent these damages in future structures, alternative reinforcement materials, which are still subject of current research, have been developed and already used in practical applications. As a reasonable alternative to conventional steel reinforcement, especially carbon fibre-reinforced polymers (CFRP) have proven to be suitable since they have a high tensile strength and high resistance to corrosion. Despite decades of research in the field, fundamental aspects such as the size effect due to its brittle behaviour or the shear capacity have not yet been fully clarified and implemented in normative regulations.

As part of the collaborative research project Carbon Concrete Composite [2], several tests were carried out on concrete members under flexural and shear loads. These members vary in regard to type of reinforcement (CFRP textile fabrics, CFRP bars, steel bars B500), cross-section (slabs, beams), loading position and failure mode (flexure, shear). The material properties and the experimental investigations are analysed 
and interpreted in terms of load-deflection behaviour, cracking behaviour and load-bearing capacity.

To evaluate the shear capacity, a photogrammetric measurement method based on digital image correlation (DIC) is used to analyse the contribution of aggregate interlock and dowelling action. By using a newly compiled shear database, the experimental shear capacities are compared with results of similar shear tests in literature.

Based on the results of the experimental investigations, an overview of the essential aspects of the structural behaviour is given. This includes deflections, crack spacings, bending and shear capacity. The applicability of existing engineering models derived for steel reinforced concrete is checked and justified.

\section{Test-setup and basic properties}

\subsection{Test-setup}

The main parameters of the experimental investigations on the bending and shear capacity of concrete members under short-term loading are summarised in Fig. 1 and Table 1 . The average effective depths of the specimens $d_{\mathrm{m}}$ were measured after failure in the critical cross section. The members with reinforcing steel were designed in such a way that the mechanical reinforcement ratio $\omega_{\mathrm{m}}=A_{\mathrm{s} / \mathrm{f}} \cdot f_{\mathrm{tm}} /\left(A_{\mathrm{c}} \cdot f_{\mathrm{cm}}\right)$ of the corresponding carbon reinforced concrete members is comparable. Due to the different tensile strengths of the reinforcement, the geometric reinforcement ratio $\rho_{\mathrm{s} / \mathrm{f}}=A_{\mathrm{s} / \mathrm{f}} / A_{\mathrm{c}}$ for the steel reinforced concrete members is significantly higher compared to the CFRP reinforced members. The ratio $\lambda=$ ald describes the distance between loading point and support in relation to the effective depth of the member.

In addition to the vertical deflections, the strains on the top and bottom side and the width of the critical shear crack were measured with strain gauges and extensometers, respectively. For the test series B a photogrammetric measurement based on digital image correlation was additionally used.

\subsection{Concrete}

For the investigations, two different normal strength concretes (C 40/50 and C 50/60) were used for the test series $A$ and $B$, respectively (see Tables 1 and 2). In order to determine the material properties of the concrete, compression and tensile splitting tests were carried out on cubes, cylinders and drill cores at different concrete ages. The results of the concrete compressive strength tests depend on the shape, size and slenderness of the specimens and are converted to the uniaxial compressive strength $f_{1, \mathrm{c}, \mathrm{m}}$ according to [3]. The uniaxial concrete compressive strength $f_{1, \mathrm{c}, \mathrm{m}}$ is approximately $7 \%$ lower than the compressive strength $f_{\text {cm,cyl }}$ determined on concrete cylinders ( $h=300 \mathrm{~mm}, d=150 \mathrm{~mm}$ ).

The concrete tensile strength $f_{\text {ctm }}$ is often determined by tensile splitting tests. According to numerical and experimental investigations by [4], the conversion factor to uniaxial concrete tensile strength

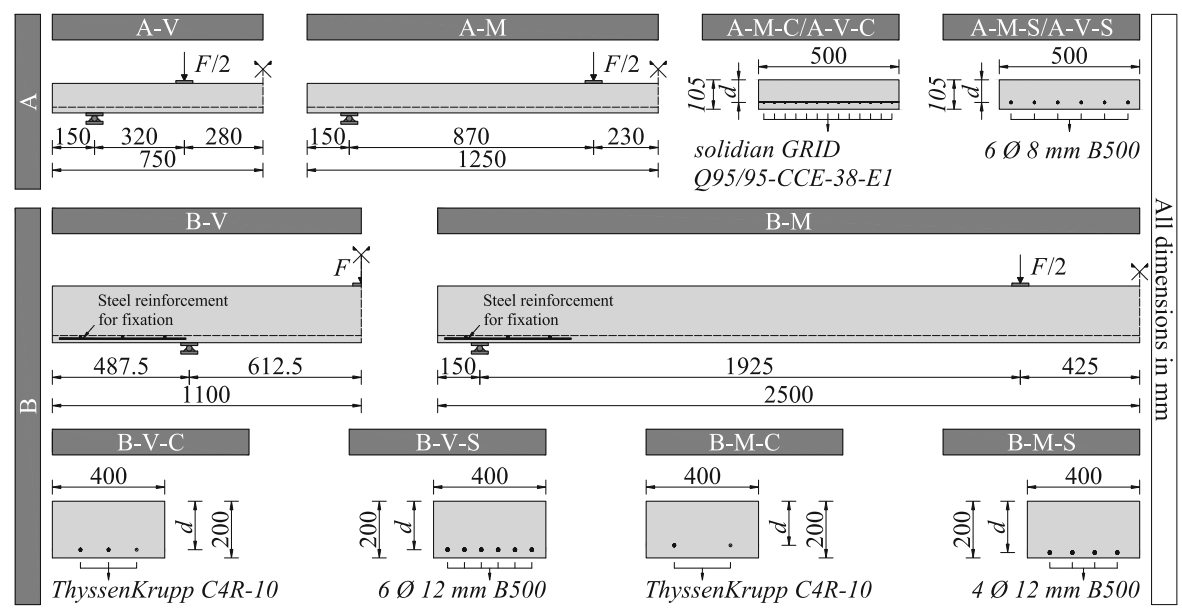

Fig. 1 Cross-sections of the test specimens and test-setups 
Table 1 Overview of the investigated test-specimens

\begin{tabular}{|c|c|c|c|c|c|c|c|c|c|}
\hline Specimen & Reinforcement & Concrete & $L_{\mathrm{m}}$ in $\mathrm{mm}$ & $h_{\mathrm{m}}$ in $\mathrm{mm}$ & $b_{\mathrm{m}}$ in $\mathrm{mm}$ & $d_{\mathrm{m}}$ in $\mathrm{mm}$ & $\lambda=a / d$ & $\rho_{\mathrm{s} / \mathrm{f}}$ in $\%$ & $\omega_{\mathrm{m}}$ in $\%$ \\
\hline A-M-C-K1 & CFRP textile & C $40 / 50$ & 2500 & 105 & 500 & 84 & 10.4 & 0.254 & 7.4 \\
\hline A-M-C-K2 & & & & & & 88 & 9.9 & 0.242 & 7.0 \\
\hline A-M-C-K3 & & & & & & 80 & 10.9 & 0.266 & 7.7 \\
\hline A-V-C-K1 & & & 1500 & & & 79 & 4.1 & 0.270 & 7.8 \\
\hline A-V-C-K2 & & & & & & 82 & 3.9 & 0.258 & 7.5 \\
\hline A-V-C-K3 & & & & & & 81 & 4.0 & 0.262 & 7.6 \\
\hline A-M-S-K1 & B500 & & 2500 & & & 73 & 11.9 & 0.824 & 9.9 \\
\hline A-V-S-K1 & & & 1500 & & & 78 & 4.1 & 0.771 & 9.3 \\
\hline B-M-C-K1 & CFRP Bars & C 50/60 & 5000 & 200 & 400 & 165 & 11.7 & 0.213 & 6.7 \\
\hline B-M-C-K2 & & & & & & 134 & 14.4 & 0.262 & 8.3 \\
\hline B-M-C-K3 & & & & & & 167 & 11.6 & 0.211 & 6.6 \\
\hline B-V-C-K1 & & & 2200 & & & 171 & 3.6 & 0.308 & 9.7 \\
\hline B-V-C-K2 & & & & & & 171 & 3.6 & 0.307 & 9.7 \\
\hline B-V-C-K3 & & & & & & 172 & 3.6 & 0.305 & 9.6 \\
\hline B-M-S-K1 & B500 & & 5000 & & & 181 & 10.6 & 0.625 & 6.2 \\
\hline B-V-S-K1 & & & 2200 & & & 172 & 3.6 & 0.987 & 9.8 \\
\hline
\end{tabular}

Table 2 Material properties of concrete

\begin{tabular}{llllllll}
\hline Specimen & Concrete & $f_{1, \mathrm{c}, \mathrm{m}}$ in $\mathrm{N} / \mathrm{mm}^{2}$ & $f_{\text {cm,cyl }}$ in $\mathrm{N} / \mathrm{mm}^{2}$ & $f_{\text {ctm }}$ in $\mathrm{N} / \mathrm{mm}^{2}$ & $\rho_{\mathrm{c}}$ in $\mathrm{g} / \mathrm{cm}^{3}$ & $E_{\mathrm{cm}}$ in $\mathrm{N} / \mathrm{mm}^{2}$ & $a_{\mathrm{g}}$ in mm \\
\hline A & C $40 / 50$ & 49.2 & 52.9 & 4.0 & 2.42 & 34,918 & 16 \\
B & C $50 / 60$ & 59.9 & 64.4 & 4.6 & 2.35 & 33,525 & \\
\hline
\end{tabular}

depends on the aggregate size and specimen geometry. In fib Model Code 2010 [5] a conversion factor of 1.0 is proposed. The results of the tensile splitting tests on concrete cubes are approximately $10 \%$ higher than those on concrete cylinders [6]. The modulus of elasticity of the concrete $E_{\mathrm{cm}}$ was determined using concrete cylinders prepared with measuring marks and strain gauges for a stress level of $\sigma_{\mathrm{c}}=0.4 \cdot f_{\mathrm{cm}}$.

\subsection{Reinforcement}

In the experiments, carbon textiles and bars were used as well as typical steel reinforcement, see Table 3 . The carbon textile is a solidian GRID Q95/95-CCE-38 impregnated with epoxy resin with a cross-sectional area of the fibres of $3.62 \mathrm{~mm}^{2}$ per strand and a mesh size of $e_{\text {mesh }}=38 \mathrm{~mm}$. The carbon bars C4R-10 by ThyssenKrupp, also impregnated with epoxy resin, are ribbed, resulting in a nominal core diameter of $d_{\mathrm{i}}=8.5 \mathrm{~mm}$.

Regarding the determination of the cross-sectional area of FRP reinforcement, different approaches exist in literature. For textiles, in many cases it is only the actual fibre cross section that is specified, since the cross section is variable over the length and the area of the fibres can be easily determined. However, for FRP bars, either the core diameter or the outer diameter of the composite is used depending on the surface processing. For this reason, the reinforcement elements were first measured by using calliper and microscope. Then the volumes were determined by immersion weighing as it is suggested in [7]. From this, averaged cross-sectional areas of the composite materials have been determined. The tensile strength of the carbon textile fabrics was determined by [8] in tensile tests according to $[9,10]$ with a free length of $160 \mathrm{~mm}$ in longitudinal direction (warp direction, $0^{\circ}$ - 
Table 3 Material properties of the reinforcement

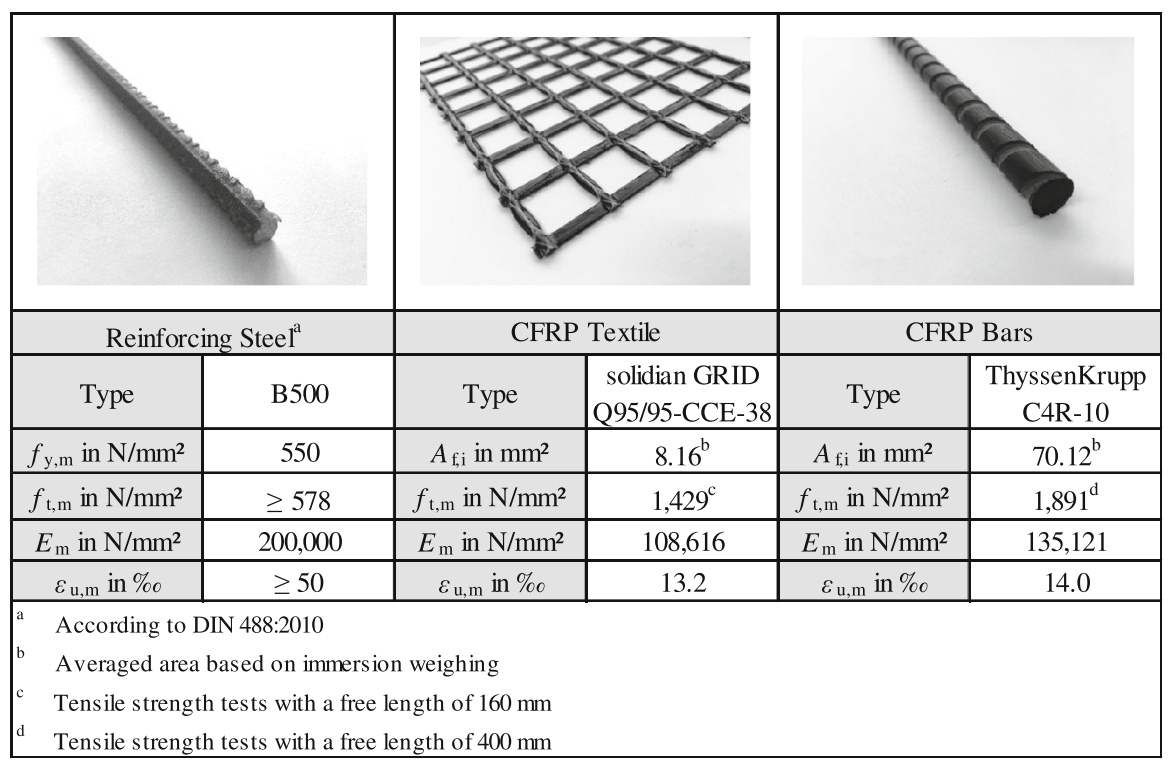

direction). Tensile tests of the carbon bars with a free length of $400 \mathrm{~mm}$ and a special clamping method were conducted at the Institute of Concrete and Masonry Structures at TU Darmstadt.

Due to the linear-elastic behaviour with brittle failure of FRP reinforcement, the length of the reinforcement in tension and the number $n$ of parallel elements have a considerable influence on the mean value and the standard deviation of the tensile strength leading to lower values for large numbers $n[9,11-13]$. For the evaluation of the ultimate bending load of concrete members, this size effect of serial and parallel systems has to be taken into account. Several aspects regarding this issue are still subject of research. First, the correlation of tensile strength and modulus of elasticity is assumed to be based on the microstructure of the material and therefore generally unknown [11]. However, a correlation between these two parameters could be assumed if the orientation and corrugation of the individual fibres are used as a justification for higher strength and modulus of elasticity. Second, the position of a single reinforcement element within a concrete member is subjected to scattering, which depends on the production process of the concrete members, so that the stresses on the individual elements are not equal. Third, it is difficult to estimate the effective reinforcement length in tension for concrete members under bending loads, as it depends on the cracking behaviour and the strain distribution in the reinforcement. The maximum strain is reached in the cross section of a crack as well as in the area near the crack. In [8], the tension length with a strain maximum is estimated to $5 \mathrm{~mm}$ per crack. An alternative to this approach can be obtained by the formulae for the determination of the crack width in [5]. Based on experimental investigations, a correction length is added to the crack spacing, which takes into account the area of disturbed bond between reinforcement and concrete near the crack and which is dependent on the concrete cover thickness $c$. This aspect will be discussed more detailed in Sect. 3.2.

\subsection{Bond}

In order to investigate the bond behaviour of concrete and reinforcement, pull-out tests including measurement of the bond stress-slip relationship were carried out on the reinforcement materials according to [14], cf. Fig. 2. The bond length was not chosen based on the reinforcement diameter $\left(l_{\mathrm{b}} / \varnothing=5\right.$ [14] $)$ but 
Fig. 2 Experimentally determined bond stress-slip relationships

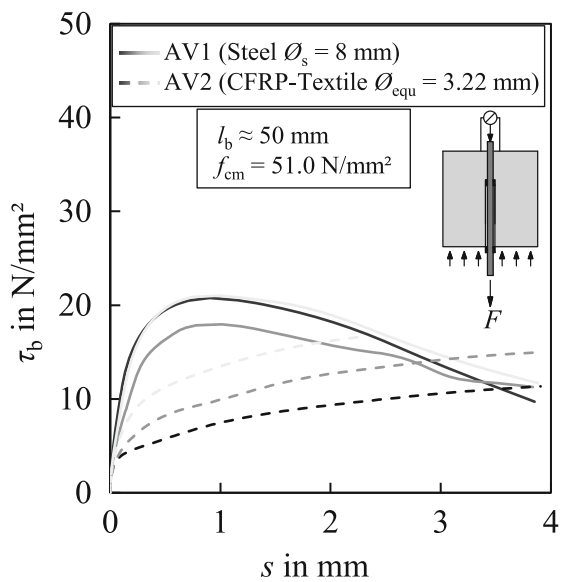

consequently set to $l_{\mathrm{b}}=50 \mathrm{~mm}$. In [15] it could be shown that the bond stresses increase by approximately $40 \%$ for a smaller ratio of $l_{\mathrm{b}} / \varnothing=2$ and the same slip. Additionally, the reinforcing steel with a diameter of $\varnothing=12 \mathrm{~mm}$ used in the bond tests showed a layer of rust on the surface, which is known to increase the bond stresses at smaller slips. Experimental investigations in [16] show an increase of the bond stresses of up to $60 \%$ at a slip of $s=0.01 \mathrm{~mm}$. At a slip of $s=0.1 \mathrm{~mm}$ the differences of the bond stresses of the bars with and without a layer of rust are negligible.

Before pull-out failure was reached, the fibre strands of the CFRP textile showed a tension failure within the bond or transition area showing a high slip at this point. The steel reinforcement bars showed typical bond stresses. For one of the specimens in series BV1 the measurement of the slip stopped shortly after reaching the maximum bond stress due to an incorrect positioning of the extensometer.

\section{Structural behaviour}

\subsection{Load-deflection- and cracking-behaviour}

The test specimens show a typical load deflection behaviour of reinforced concrete members which is shown in Fig. 3. From $M=0$ up to the crack moment $M=M_{\text {cr }}$ the cross-section of the specimens is uncracked (state I). Between $M=M_{\text {cr }}$ and approximately $M=1.3 M_{\text {cr }}$ the specimens are in the crack formation phase (state IIa), followed by the (almost) stabilised cracking state IIb. For specimens with steel reinforcement and bending failure yielding of the reinforcement leads to state III. For the specimens of the series A-M as well as for the test B-M-C-K1, the specimens were temporarily unloaded when state IIb was reached and extensometers were attached to measure the crack width. Due to the unloading and reloading, the tension stiffening effect is reduced, even if only to a small extent.

The test specimens mainly subjected to bending loads and reinforced with CFRP showed a tension failure of the reinforcement. In the reference members with steel reinforcement A-M-S-K1 and B-M-S-K1, the reinforcement first reached the yield strength. The strain of the reinforcement in the crack increases disproportionally with further loading until the strain in concrete on the top side reaches a critical value and concrete compression failure occurs.

In the case of the $\mathrm{A}-\mathrm{V}$ and $\mathrm{B}-\mathrm{V}$ members, which were predominantly subjected to shear, all the members failed to shear except for the A-V-S-K1 member. When comparing the members $\mathrm{A}-\mathrm{V}-\mathrm{C}$ to the member $\mathrm{A}-\mathrm{V}-\mathrm{S}-\mathrm{K} 1$, it can be seen that the mechanical reinforcement ratio $\omega_{\mathrm{m}}$ and therefore the bending capacity is in the same order of magnitude. Due to the lower tensile strength of steel, much more reinforcement is needed leading to a higher geometric reinforcement ratio and therefore to a higher concrete compression zone and a higher shear capacity. Because of the higher shear capacity, bending failure becomes decisive for the member A-V-S-K1. The maximum force at failure and the failure mechanisms are summarised in Table 4.

The crack patterns of the different specimens were recorded, visualised and evaluated during the test and 

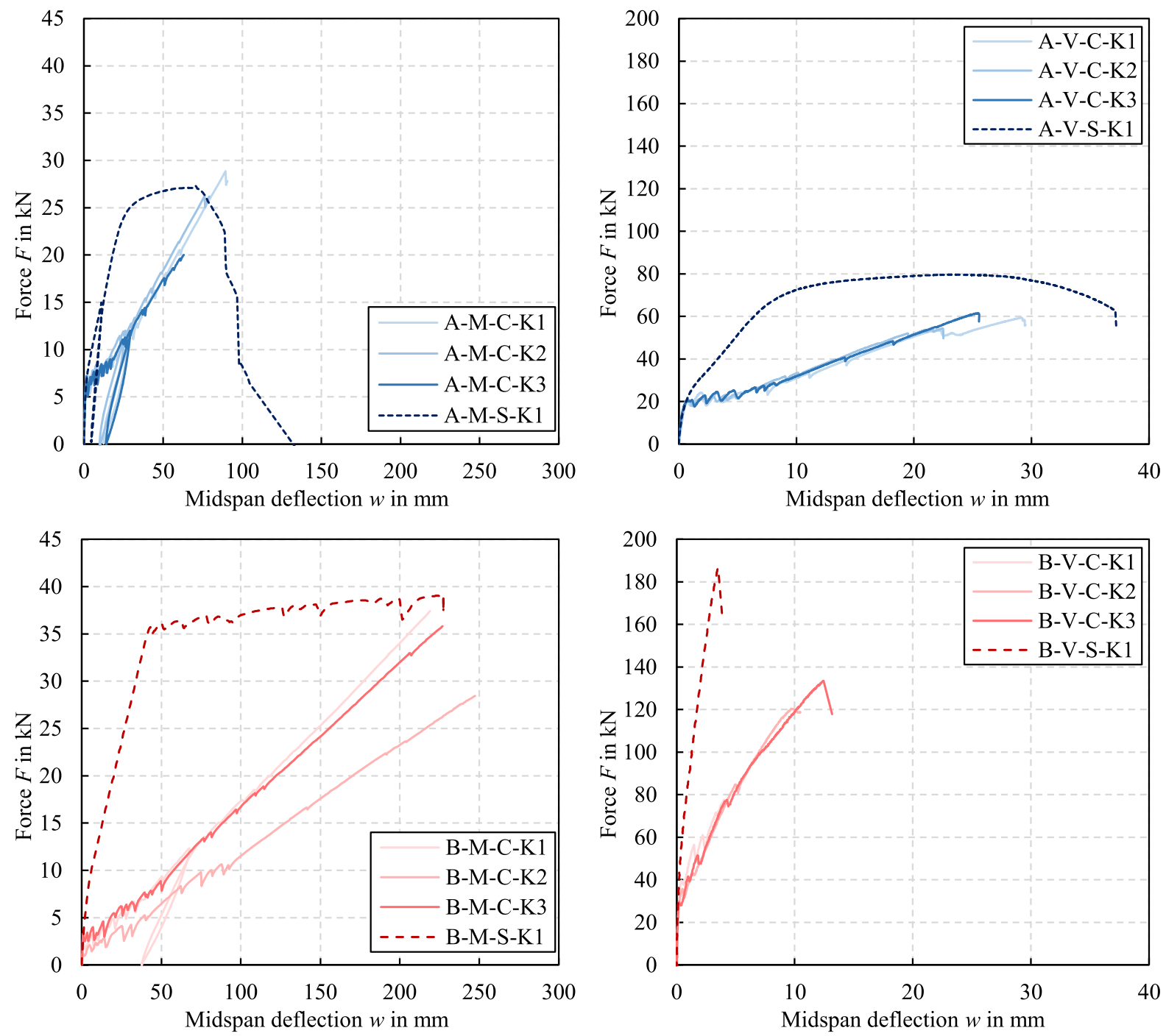

Fig. 3 Load-deflection behaviour of the reinforced concrete members

after failure. The crack patterns at failure including the critical failure crack marked in red are shown in Fig. 4.

The test specimens subjected predominantly to flexural loads show typical bending cracks. In member A-M-C-K3, a horizontal delamination crack occurred shortly before failure, which spread from the centre towards the two loading points. This horizontal crack is caused by the changing vertical position of the textile over the length of the member. In the centre, the textile is positioned slightly higher than at the loading points leading to vertical forces at the redirection points. Due to this delamination, the concrete in the tension zone is no longer active and the strain in the reinforcement is almost constant over the length of the delamination crack. Due to the size effect resulting from the higher length in tension, the failure load is significantly reduced [8].

Comparing the specimens A-M-C/A-V-C and A-M-S/A-V-S, it is obvious that the crack spacings are in a comparable order of magnitude, although the geometric reinforcement ratio differs significantly. This is particularly due to the transverse reinforcement of the CFRP textiles. Despite the smooth surface, the irregular structure of the textiles leads to a form-fit based bonding mechanism that acts like a mechanical interlock [17-21]. For the specimens of the B-series, the crack spacings of the members with CFRP reinforcement are much higher than those of the 
Table 4 Crack spacings, maximum force and failure mechanism

\begin{tabular}{lrrllll}
\hline Specimen & $s_{\mathrm{r}, \min }(\mathrm{mm})$ & $s_{\mathrm{r}, \text { mean }}(\mathrm{mm})$ & $s_{\mathrm{r}, \max }(\mathrm{mm})$ & $s_{\mathrm{r}, \text { mean }} / s_{\mathrm{r}, \max }(-)$ & $F_{\max }(\mathrm{kN})$ & Failure \\
\hline A-M-C-K1 & \multicolumn{1}{c}{56} & 89 & 134 & 0.66 & 28.9 & Flexure \\
A-M-C-K2 & 55 & 80 & 111 & 0.72 & 26.2 & \\
A-M-C-K3 & 52 & 84 & 121 & 0.69 & 20.0 & \\
A-M-S-K1 & 57 & 81 & 101 & 0.80 & 27.3 & \\
B-M-C-K1 & 45 & 71 & 87 & 0.82 & 37.4 & \\
B-M-C-K2 & 57 & 81 & 109 & 0.74 & 28.5 & \\
B-M-C-K3 & 51 & 80 & 106 & 0.75 & 35.8 & \\
B-M-S-K1 & 53 & 71 & 107 & 0.66 & 39.0 & \\
A-V-C-K1 & 103 & 168 & 265 & 0.63 & 59.4 & Shear \\
A-V-C-K2 & 81 & 194 & 346 & 0.56 & 54.4 & \\
A-V-C-K3 & 90 & 169 & 244 & 0.69 & 61.5 & \\
A-V-S-K1 & 137 & 166 & 184 & 0.90 & 79.7 & Flexure \\
B-V-C-K1 & 84 & 162 & 249 & 0.65 & 128.2 & Shear \\
B-V-C-K2 & 106 & 146 & 177 & 0.83 & 120.4 & \\
B-V-C-K3 & 30 & 134 & 216 & 0.62 & 133.7 & \\
B-V-S-K1 & 41 & 99 & 157 & 0.63 & 186.3 & \\
\hline
\end{tabular}

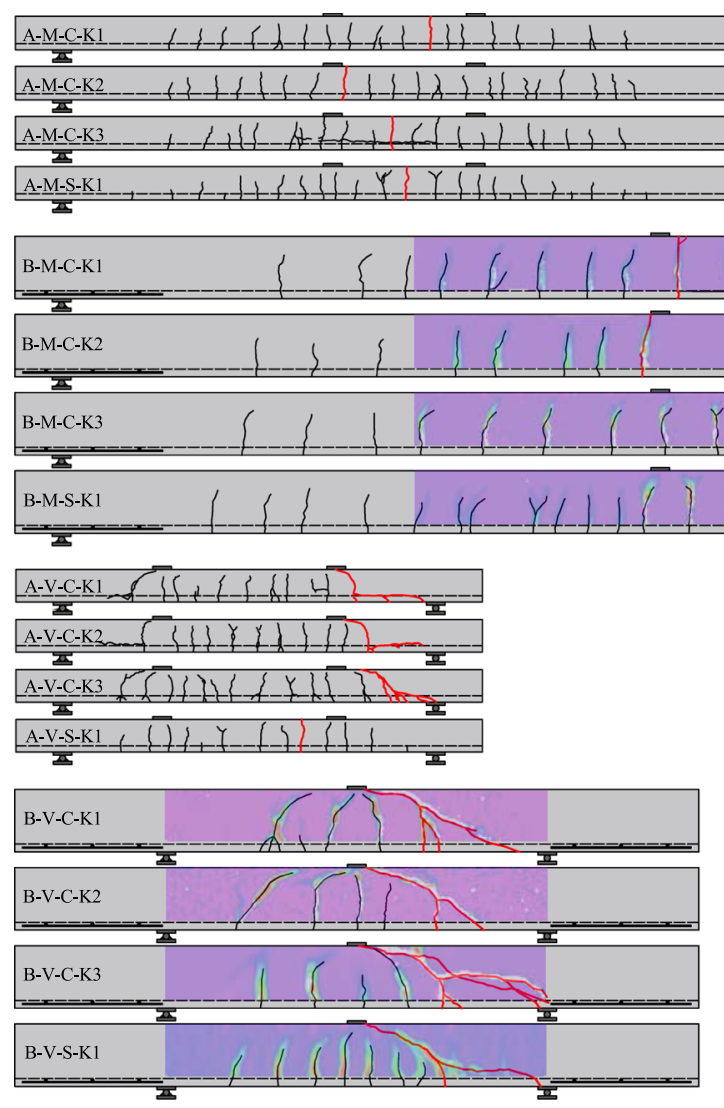

Fig. 4 Crack patterns at failure and DIC measurement 
members with reinforcing steel, cf. Figure 4 and Table 4.

The failure cracks within the test series A-V-C differ with respect to the distance of the critical shear crack to the loading point. In the tests A-V-C-K1 and A-V-C-K2, the critical shear crack is located close to the loading point. With increasing distance from the loading point, the ratio of normal stresses to shear stresses decreases and therefore the inclination angle in the axis of the reinforcement has to increase. Another crack does not open. In the test A-V-C-K3, two cracks open to the right of the load introduction. The critical shear crack has an obvious inclination. The steel reinforced reference test A-V-S-K1 failed on flexure with a failure crack in the centre of the specimen. The test series B-V shows a more consistent behaviour. The critical shear cracks occur at a comparable distance to the loading point and show a comparable course. The reference test B-V-S-K1 also shows a shear failure, but shows finer distributed bending cracks.

In [22] the ratio of mean value to maximum value of the crack spacing, based on theoretical investigations by $[23,24]$, is assumed to be between the values 0.58 and 0.72 . With increasing bending load and shear slenderness, the members get closer to a stabilised crack pattern and the ratio decreases, which is clearly noticeable in the values given in Table 4. Considering that the crack spacing is highly dependent on the concrete tensile strength, the bond strength and various other parameters such as reinforcement ratio, reinforcement diameter and loading situation, a scattering of the value $s_{\mathrm{r} \text {,mean }} / s_{\mathrm{r}, \text { max }}$ is expectable.

According to fib Model Code 2010 [5] the maximum distance between two cracks $s_{r \text {,max }}$ equals twice the transfer length $l_{\mathrm{t}}$ (length over which slip between concrete and reinforcement occurs). In [5] a correction length proportional to the concrete cover thickness is added to take into account the area near the crack where the bond is disturbed. This aspect in particular is heavily discussed as it leads to very high crack spacings for higher concrete covers. As suggested by [22] and verified by experiments, the ratio for mean to maximum crack spacing is taken to 0.72 which leads to $s_{\mathrm{r}, \mathrm{m}}=1.44 l_{\mathrm{t}}$. The mean value of the crack spacing $s_{\mathrm{r}, \mathrm{m}}$ according to $[22,25]$ neglecting the influence of the concrete cover is based on an equilibrium of the tension and bond force and can be calculated via Eq. (1). $s_{r, m}=1.44 \cdot l_{\mathrm{t}}=1.44 \cdot\left(0.25 \cdot \frac{f_{\mathrm{ct}, \mathrm{eff}}}{\tau_{\mathrm{bm}}} \cdot \frac{\phi_{\mathrm{s} / \mathrm{f}}}{\rho_{\mathrm{s} / \mathrm{f}, \mathrm{eff}}}\right)$

$l_{\mathrm{t}}$ transfer length (length over which slip between concrete and reinforcement occurs), $f_{\text {ct,eff }}=0.8 f_{\text {ctm }}$ (reduced value of mean concrete tensile strength), $\tau_{\mathrm{bm}}$ mean bond stress between concrete and reinforcement, $\emptyset_{\mathrm{s} / \mathrm{f}}$ diameter of reinforcement element, $\rho_{\mathrm{s} / \mathrm{f} \text {,eff }}=A_{\mathrm{s} / \mathrm{f}} \mathrm{l}$ $A_{\mathrm{c}, \text { eff }}$ ratio of area of reinforcement to effective area of concrete in tension, $A_{c, \text { eff }}=b \cdot h_{\mathrm{c} \text {,eff }}$; where $h_{\mathrm{c}, \mathrm{eff}}=\min (2.5(h-d) ; h / 2 ; h / 3-x / 3)$ effective tensile area of concrete; value 2.5 can be modified [5].

Among the decisive factors to determine the crack spacing are the mean bond stress and the effective tensile concrete area. The equations for the determination of $A_{\mathrm{c}, \text { eff }}$ were derived and investigated by [26] using nonlinear FE calculations. It was found that the required force to open the next crack is only marginally influenced by parameters such as the reinforcement ratio, the mathematical description of concrete under tension, the bond behaviour and the concrete strength. With regard to the average bond stress, the value of $\tau_{\mathrm{bm}}=2.25 f_{\mathrm{ctm}}$ specified in [25] is a very simplified assumption which applies to a maximum slip of $s=0.25 \mathrm{~mm}$ (crack width $w=0.5 \mathrm{~mm}$ ), even though the ratio of average bond strength to concrete tensile strength seems to decrease with higher concrete compressive strength and changes dependent on the crack width.

The bond failure of ribbed steel reinforcement in case of pull-out is determined by the failure of the concrete corbels. As described in Sect. 3.1, in the case of textile CFRP reinforcement, the bond is achieved by form-fit, which results from the irregular crosssectional shape and the periodic widening of the strands. In the large-scaled member tests carried out, an evident influence of the transverse reinforcement was also noticed. Cracks usually occurred in the area of the transverse reinforcement. In the case of CFRP bars with milled ribs, a failure of the bar profile is often decisive above a certain concrete strength. A determination of the bond strength proportional to the concrete strength is therefore only possible up to the failure limit of the profile.

As the mean bond stress is dependent on the slip, the crack width $w$ in the stabilised cracking state (1.3 $M_{\text {cr,calc }}$ ) is calculated based on the measurement of the strains at the bottom side of the specimens. Using the 


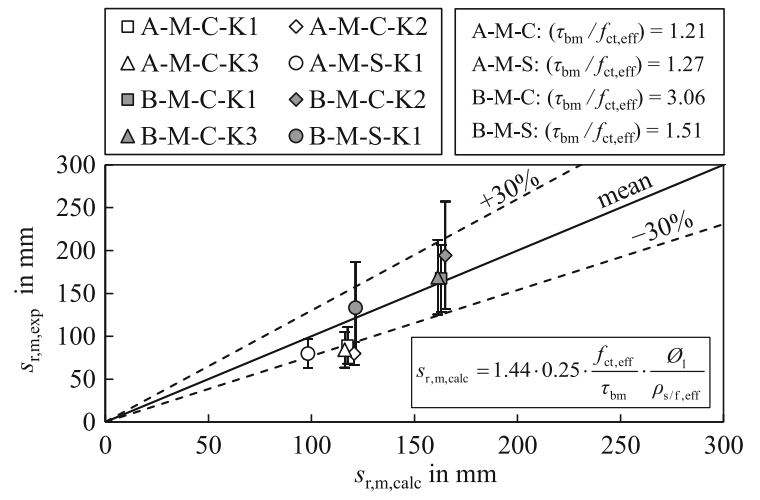

Fig. 5 Comparison of experimental and calculated values of mean crack spacings including standard deviation

crack widths, the mean bond stress for a slip of $s=w / 2$ can be determined from the pull-out tests described in Sect. 2.4. The results are shown in Fig. 5, where the experimental and calculated mean values of the crack spacings including the standard deviations are compared.

As can be seen in Fig. 5, the experimental und calculated values generally show a good agreement. The highest deviations are determined for the textilereinforced members. This is attributed to the strong influence of the transverse reinforcement. In existing normative regulations [27] for structures with steel reinforcement meshes, the maximum crack spacing is limited to the value of two meshes. In Fig. 6, the measured crack spacings of the textile-reinforced members A-M-C are analysed in detail. In this Figure, every single measured crack spacing $s_{\mathrm{r}, \mathrm{exp}, \mathrm{i}}$ (53 in total) of the A-M-C specimens is plotted over the index $i$ from $i=1$ to $i=53$ on the abscissa. The mean value of all crack spacings $s_{\mathrm{rm} \text {,exp }}$ is compared to the double and triple mesh size of the textile fabric. It is obvious that the mean value of the crack spacing corresponds to twice the mesh size, which can be clearly confirmed by analysing photographs of the members. The maximum crack spacing in the members rarely exceeds triple the mesh size. Due to scattering of the concrete tensile strength, cracks partly cross each other, but are usually located in the axes of the transverse reinforcement. A precise calculation of the crack spacings without closer examination of the influence of transverse reinforcement is therefore only partly possible for textilereinforced concrete members.

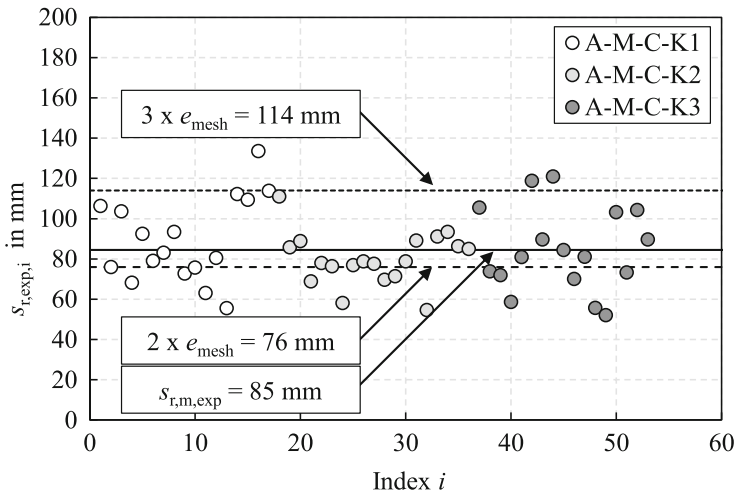

Fig. 6 Crack spacings compared to the mesh size

\subsection{Ultimate bending load}

As described in Sect. 2.3, in order to determine the ultimate bending moment, the size effect resulting from the length of the reinforcement in tension and the number of parallel elements must be taken into account.

To calculate the number of serial elements $n_{\text {serial }}$, the length of a reinforcing element in tension $L_{\text {serial }}$ is related to the free length of the tensile strength tests $L_{\text {tension-test. }}$ The reinforcement strain reaches a peak value in the cracked section. In a small area near the crack, it is assumed that the bond between concrete and reinforcement can be regarded as disturbed, leading to an area of constant reinforcement strain. The length of this region seems to be dependent on the concrete cover (cf. Section 2.3 and determination of crack width according to [5]). If a delamination crack occurs (specimen A-M-C-K3), the length of this horizontal crack is also added to the reinforcement length in tension. Therefore, the number of serial elements $n_{\text {serial }}$ and the length of the reinforcement in tension with a maximum tensile strain $L_{\text {serial }}$ can be calculated by Eq. (2).

$n_{\text {serial }}=\frac{L_{\text {serial }}}{L_{\text {tension-test }}}=\frac{n_{\text {crack }} \cdot L_{\text {crack }, i}+L_{\mathrm{del}, i}}{L_{\text {tension-test }}}$

$n_{\text {serial }}$ number of serial elements, $L_{\text {serial }}$ length of a reinforcing element in tension with maximum tensile strain, $n_{\text {crack }}$ number of cracks in the area of constant bending moment, $L_{\text {crack }, i}$ length with constant strain for each crack (here: $L_{\text {crack, } i}$ equals concrete cover $c$ ), $L_{\mathrm{del}, i}$ length of delamination crack.

Since parallel systems behave like serial systems in terms of the reduction of the mean value of the tensile 
strength, it is sufficient to consider them as additional serial elements. The equivalent number of serial elements $n_{\text {mod }}$ is therefore described by Eq. (3).

$n_{\text {mod }}=n_{\text {serial }} \cdot n_{\text {parallel }}$

With this number of equivalent elements, the failure probability $p_{\text {mod }}$ of a system with $n_{\text {mod }}$ elements can be calculated according to [9] and Eq. (4).

$p_{\text {mod }}=1-0.5^{1 / n_{\text {mod }}}$

If, as an example, the reduced mean value is calculated for a system with $n_{\text {mod }}=10$ elements, the reduced probability is $p_{\text {mod }}=0.067$. Assuming a normal distribution, the tensile strength $f_{\mathrm{tm} \text {,mod }}$ for this probability can now be determined. This can be done using typical standard normal distribution tables with the corresponding z-scores and the standard deviation of the tensile strength tests.

The reduction factor of the FRP tensile strength $f_{\mathrm{tm}, \bmod } / f_{\mathrm{tm}}$ as a function of the number of serial and parallel elements for the CFRP textiles and bars is shown in Fig. 7.

With this reduced tensile strength and the constitutive laws of concrete and reinforcement, the ultimate bending moment can be determined by iterating the strain plane and fulfilling force equilibrium. The results of the calculations are shown in Table 5. The ratio of experimental and calculated ultimate bending moments is in average 1.06 for all tests and thus provides good agreement with the models.

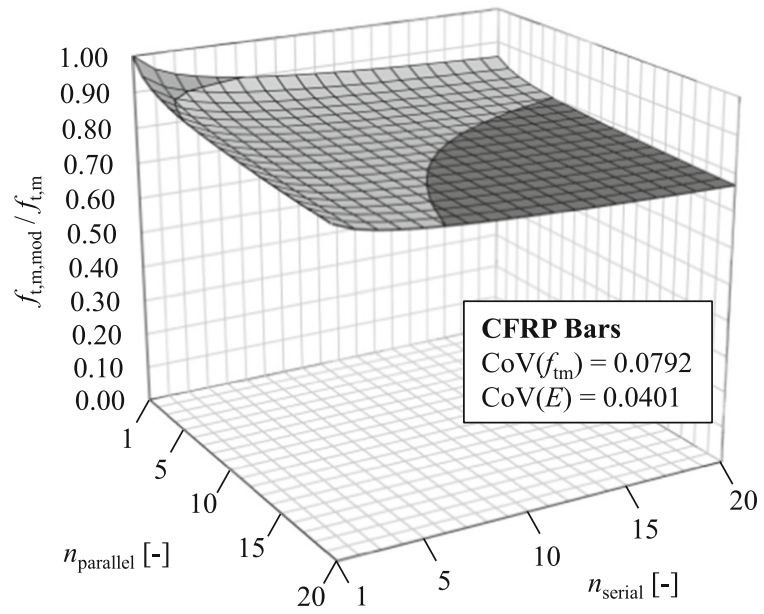

Fig. 7 Reduction factor considering serial and parallel elements

\section{Shear strength}

\subsection{General background}

For the shear capacity of reinforced concrete members without shear reinforcement, numerous models and analytical approaches exist, some of which are still empirical to this day. The shear capacity is characterised by different mechanisms.

$V_{\text {cc }} \quad$ Shear capacity of the non-cracked concrete compression zone

$V_{\mathrm{rs}} \quad$ Residual tensile stresses in the fracture process zone

$V_{\text {agg }} \quad$ Aggregate interlock

$V_{\text {dow }}$ Dowelling action of the longitudinal reinforcement

In the cracked state II shear forces can be transferred through the non-cracked concrete compression zone. In the area of the fracture process zone, whose size depends on the material properties of the concrete according to Zink [28], crack-bridging tensile forces are transferred in case of small crack widths. As a further mechanism Reineck [29] mentions the aggregate interlock and friction along the critical shear crack. According to Walraven [30], this mechanism is decisively influenced by the shape and size of the aggregate. Oblique crack openings cause a vertical displacement of the two crack sides and activate the dowel effect of the longitudinal reinforcement, which according to Baumann and Rüsch [31] is described by the elastic bedding of the longitudinal reinforcement.

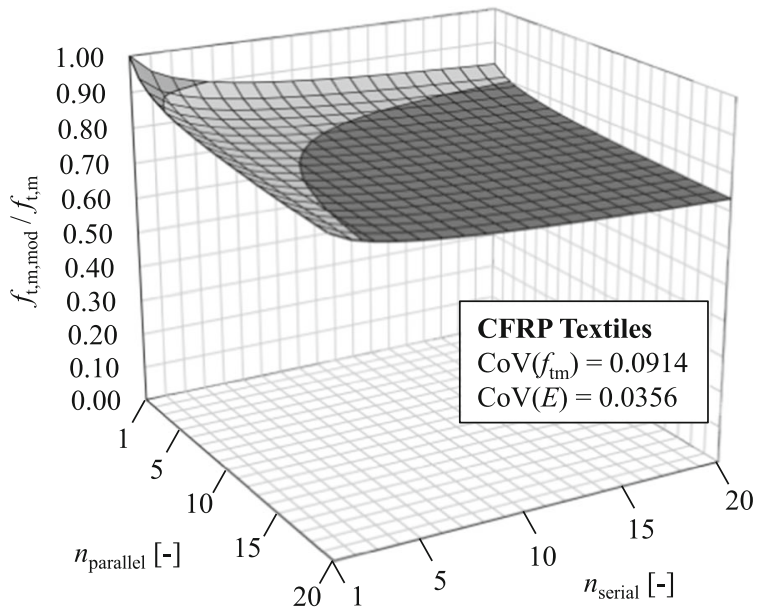




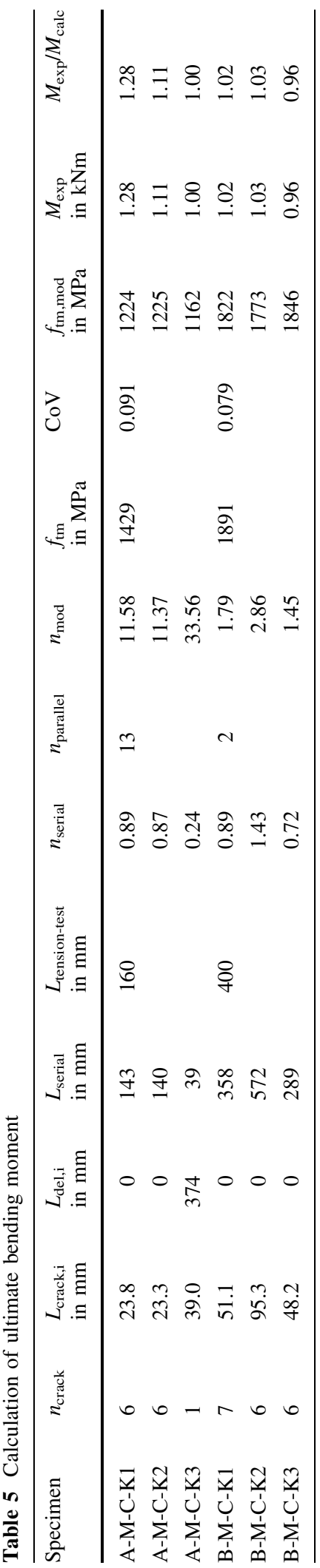

As the loads increase, shear cracks form from bending cracks, which propagate at the level of the longitudinal reinforcement in the direction of the support and on the upper side in the direction of the loading points. The load-bearing behaviour changes and the deformations increase. For members with a low reinforcement ratio, this system change can lead to a sudden failure according to Hegger and Görtz [32], while for members with a high reinforcement ratio, a redistribution and thus a significant increase in load is still possible.

These different mechanisms show that the shear capacity depends on a large number of parameters. In addition to the modulus of elasticity of concrete and reinforcement, shape and maximum diameter of the aggregate, concrete tensile strength, reinforcement ratio and member height, the shear slenderness of the beam $\lambda=M_{\max } /\left(V_{\max } \cdot d\right)$ is of particular importance, which corresponds to the distance between the loading point and the support in relation to the effective depth $\lambda=a / d$ in the case of single loads. The dependence of the shear capacity on the shear slenderness is often described by the so-called shear valley according to Kani [33]. It describes the fact that the ratio of an experimentally determined maximum bending moment $M_{\mathrm{u}, \exp }$ and the maximum possible bending capacity $M_{\mathrm{u}, \mathrm{cal}}$ takes on a minimum value at a shear slenderness of approximately $\lambda=2.5$ with shear failure becoming decisive.

Despite intensive investigations in the past decades, the shear capacity of concrete members without shear reinforcement is still subject of current research and is not finally solved [34, 35]. Due to the transversely isotropic material behaviour and the low strength perpendicular to the fibre direction of the FRP reinforcement, a direct transferability of the load-bearing mechanisms, in particular of the dowel effect, cannot be assumed without further investigations [36]. In addition, FRP reinforcement typically has a lower modulus of elasticity, which reduces the longitudinal stiffness of the reinforcement and thus the height of the concrete compression zone leading to lower shear capacities [37].

\subsection{Prediction of shear strength}

Due to the large number of influencing parameters and different load-bearing mechanisms, the prediction of the shear capacity of concrete members without shear 
reinforcement is often accompanied by large scattering. For a comparison of the shear capacity of members with CFRP reinforcement as well as conventional steel reinforcement the shear model described in $[38,39]$ was used.

To compare the calculated and experimentally determined shear capacities, the shear database for steel-reinforced concrete members by [40] $(n=551)$ was used. In addition, a shear database for members with FRP reinforcement [41-58] $(n=186)$ has been compiled and the results are compared with the tests presented in this paper. Only tests with complete data and adhering the following criteria were evaluated:

$\lambda \geq 2,5$

$f_{1, \mathrm{c}, \mathrm{m}} \geq 12 \mathrm{~N} / \mathrm{mm}^{2}$

$b_{\mathrm{w}} \geq 50 \mathrm{~mm}$

$b_{\mathrm{w}}=b$

$h \geq 70 \mathrm{~mm}$

Figure 8 shows a comparison of the experimental data given in this article and in literature for shear capacities of steel and FRP reinforced concrete members with the calculated values using the model described in $[38,39]$. The mean value of the experimental shear capacity in relation to the calculated values is 1.01 for steel reinforced concrete members. This value is just slightly higher for FRP reinforced concrete members which leads to the assumption that the shear model is accurate for FRP members and that the shear behaviour is comparable to steel reinforced concrete members.

\subsection{Analysis of shear mechanisms}

The critical shear crack first develops from a vertically oriented bending crack at a distance of $1.0 d$ to $a / 2$ from the loading point. The bending crack then proceeds diagonally, usually at an angle of $45^{\circ}$, towards the loading point until it reaches the neutral axis at the transition to the concrete compression zone. If the load is increased, this crack develops further at a flatter angle and breaks through the compression zone. This critical condition is often referred to as the point of maximum shear strength, since the system often becomes unstable and the load can only be increased very slightly. For the tests of the B-series, an additional deformation measurement using digital

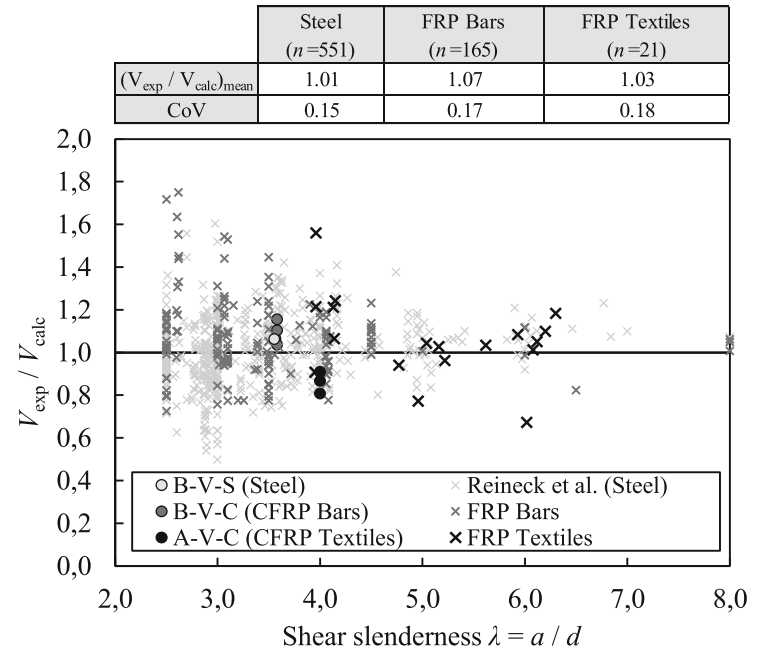

Fig. 8 Comparison of experimental shear capacities and predictions using the model in [38, 39]

image correlation was used and which allows for a precise measurement of crack widths in failure state. The DIC measurement and crack pattern at different load stages of specimen B-V-C-K1 is shown in Fig. 9

In the literature, the relevant shares of the shear capacity are still discussed today [59]. The main loadbearing mechanisms mentioned are based on the noncracked concrete compression zone and aggregate interlock. According to [28], the distribution of shear stresses in the compression zone can be assumed to be parabolic. The shear capacity of the non-cracked concrete compression zone $V_{\mathrm{cc}}=2 / 3 \cdot \tau_{\max } \cdot b \cdot x$. Zink [28] states that the maximum shear stress $\tau_{\max }$ equals the concrete tensile strength $f_{\text {ct }}$ if the crack tip is located at the neutral axis.

Numerous studies have been carried out to investigate aggregate interlock as a transfer mechanism of shear stresses [30, 60-62]. Based on the principles given in [60, 63], Herbrand and Hegger [64] propose the following description for the shear stresses with a critical shear crack width to limit the transfer capability.

$\tau_{\mathrm{ai}}=\frac{0.14 \cdot \sqrt{f_{\mathrm{ck}}}}{0.31+\frac{24 w}{a_{\mathrm{g}}+16}}\left(1-\frac{w}{w_{0}}\right)$

$1.0 \leq w_{0}=2.0-0.1 \cdot\left(f_{\mathrm{ck}}-50\right) \leq 2.0\left(w_{0}\right.$ in $\left.\mathrm{mm}\right)$ 
Fig. 9 DIC measurement and crack pattern at different load stages

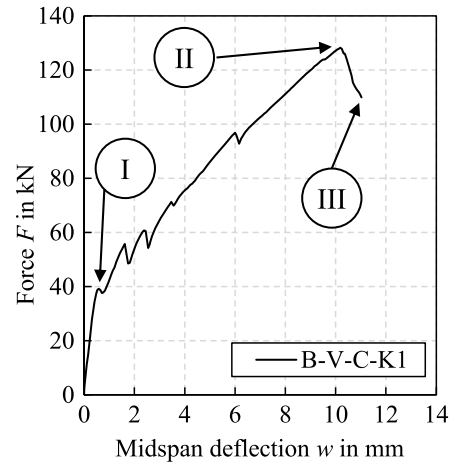

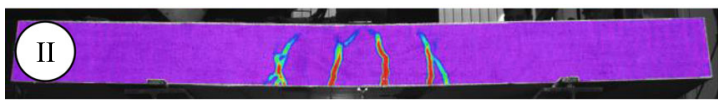
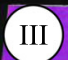

shows the results of the analysis of the relevant shares

$f_{\text {ck }}$ characteristic concrete compressive strength, $f_{\mathrm{ck}}=f_{\mathrm{cm}}-4 \mathrm{MPa}$ according to [40], $w$ crack width in $\mathrm{mm}, a_{\mathrm{g}}$ maximum aggregate size in $\mathrm{mm}$.

Besides these two mechanisms, the dowelling action and the residual tensile stresses in the fracture process zone in the vicinity of the crack tip have to be mentioned. Based on the DIC-measurement of crack width $w$ and slip $s$ these two mechanisms can be evaluated. The tensile residual stresses in the fracture process zone are calculated based on the stress-crack width-relation given in [5]. The dowelling action is calculated according to [59] using the measurement of the slip $s$ at the critical shear crack.

Especially since shear failure is a sudden failure, slight discrepancies between the recorded strains of the DIC system and the force measurement can occur due to different measuring frequencies. Figure 9 of the shear capacity as well as an exemplary illustration of the stress and force distribution in the critical shear crack.

As can be seen in Fig. 10, a good agreement can be found between the determined load shares and the actual shear force capacities, even if the respective shares are partly overestimated or underestimated for the individual specimens. The member B-V-S-K1 showed the highest divergence with a deviation of $14 \%$. Especially for small crack widths, a very high resolution of the DIC cameras is needed. Since the crack patterns on the front and back are not identical, the share of aggregate interlock is difficult to estimate despite the refined DIC measurement. However, it is obvious that these load-bearing mechanisms provide the main part of the shear capacity.
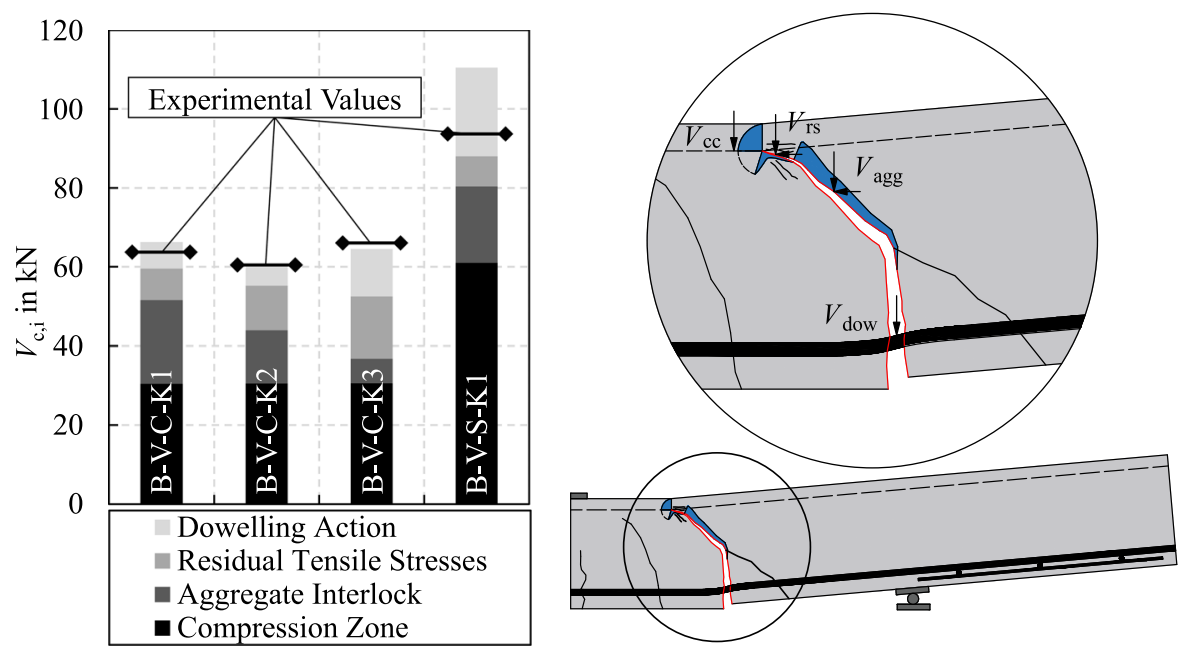

Fig. 10 Relevant shares of shear capacity 


\section{Conclusions}

In the presented experimental and theoretical investigations on the load-bearing and deformation behaviour of concrete members reinforced with carbon fibre-reinforced polymer reinforcement, the bending and shear capacity as well as the cracking behaviour are discussed. For this purpose, the necessary material parameters as well as the special characteristics of FRP reinforcement, such as the size effect, are described in detail. Pull-out tests are carried out to characterise the bond behaviour between concrete and reinforcement. Firstly, it turns out that the maximum bond strength seems to be lower for the studied FRP reinforcement, but the influence on the resulting crack spacings is rather small, since only the mean bond stresses at small slips are required. Secondly, it can be seen that the transverse reinforcement of CFRP textiles has a strong influence on the cracking behaviour. Using the information about the cracking behaviour and the size effect for FRP reinforcement, the tensile strengths are reduced by considering serial and parallel elements. With this information the bending capacities are determined and compared to the experimental values. Finally, the tests on the shear capacity are analysed and evaluated using an existing engineering model. For a more precise analysis, an existing test database for steel reinforced concrete members is used and a new database for concrete members with FRP reinforcement is compiled. The individual shares of the shear capacity are then analysed and evaluated using photogrammetric measurement technology based on digital image correlation. It turns out that the experimental and calculated values show a good agreement. The shear behaviour of reinforced concrete members with CFRP reinforcement is similar to the behaviour of steel reinforced concrete members.

Acknowledgements Open Access funding provided by Projekt DEAL. The authors would like to thank the German Federal Ministry of Education and Research for the support and funding of the research project "C3-V2.1 - Long-term behaviour of Carbon Concrete", the company solidian for providing the textile reinforcement and the company Goldbeck for the production and supply of the concrete members.

\section{Compliance with ethical standards}

Conflict of interest The authors declare that they have no conflict of interest.
Open Access This article is licensed under a Creative Commons Attribution 4.0 International License, which permits use, sharing, adaptation, distribution and reproduction in any medium or format, as long as you give appropriate credit to the original author(s) and the source, provide a link to the Creative Commons licence, and indicate if changes were made. The images or other third party material in this article are included in the article's Creative Commons licence, unless indicated otherwise in a credit line to the material. If material is not included in the article's Creative Commons licence and your intended use is not permitted by statutory regulation or exceeds the permitted use, you will need to obtain permission directly from the copyright holder. To view a copy of this licence, visit http://creativecommons.org/licenses/by/4.0/.

\section{References}

1. Zintel M, Angst U, Keßler S et al (2014) Epoxidharzbeschichtete Bewehrung - Neue Erkenntnisse nach zwei Jahrzehnten Praxiserfahrung. Beton- und Stahlbetonbau 109:3-14

2. Lieboldt M, Tietze M, Schladitz F (2018) $C^{3}$-Projekt Erfolgreiche Partnerschaft für Innovation im Bauwesen. Bauingenieur 7(8):265-273

3. Grübl P, Weigler H, Karl S (2001) Beton. Arten, Herstellung und Eigenschaften, 2nd edn. Ernst and Sohn, Berlin

4. Malárics V, Müller HS (2007) Experimental and numerical analysis of the fracture process in the splitting tension test of concrete. In: Carpinteri A (ed) Fracture mechanics of concrete and concrete structures: proceedings of the 6th international conference of fracture mechanics of concrete and concrete structures, Catania, Italy, 17-22 June 2007. pp 225-232

5. International Federation for Structural Concrete (2013) fib Model Code 2010 for concrete structures

6. Deutsches Institut für Normung e V (2010) DIN EN 12390-6 - Prüfung von Festbeton - Teil 6: Spaltzugfestigkeit von Probekörpern

7. ASTM International (2016) D7205/D7205M - 06 (Reapproved 2016) - Standard Test Method for Tensile Properties of Fiber Reinforced Polymer Matrix Composite Bars

8. Rempel S (2018) Zur Zuverlässigkeit der Bemessung von biegebeanspruchten Betonbauteilen mit textiler Bewehrung. Dissertation, RWTH Aachen

9. Rempel S, Ricker M (2017) Ermittlung der Materialkennwerte für die Bemessung von textilbewehrten Bauteilen. Bauingenieur 92:280-288

10. Hinzen M (2017) Prüfmethode zur Ermittlung des Zugtragverhaltens von textiler Bewehrung für Beton. Bauingenieur 92:289-291

11. Vořechovský M, Chudoba R (2006) Stochastic modeling of multi-filament yarns: II. Random properties over the length and size effect. Int J Solids Struct 43:435-458

12. Weibull W (1951) A statistical distribution function of wide applicability. J Appl Mech 18:293-297

13. Gollwitzer S, Rackwitz R (1990) On the reliability of Daniels systems. Struct Saf 7:229-243

14. Rilem TC (1994) RC 6: bond test for reinforcement steel, 2. Pull-out test, 1983. In: RILEM recommendations for the 
testing and use of construction materials. E \& FN SPON, London, pp 218-220

15. Ritter L (2013) Der Einfluss von Querzug auf den Verbund zwischen Beton und Betonstahl. Technische Universität Darmstadt, Institut für Massivbau, Dissertation, Dresden

16. ISB-Bericht 7-10/92 (1992) Verbundverhalten blanker und verrosteter, gerippter Bewehrungsstähle. Institut für Stahlbetonbewehrung e. V.(ISB-Bericht 7-10/92)

17. Schütze E, Curbach M (2019) Zur experimentellen Charakterisierung des Verbundverhaltens von Carbonbeton mit Spalten als maßgeblichem Versagensmechanismus. Bauingenieur 94:133-141

18. Preinstorfer P, Kromoser B, Kollegger J (2018) Einflussparameter auf die Spaltrissbildung in Textilbeton. Beton- und Stahlbetonbau 113:877-885

19. Bielak J, Spelter A, Will N et al (2018) Verankerungsverhalten textiler Bewehrungen in dünnen Betonbauteilen. Beton- und Stahlbetonbau 113:515-524

20. Preinstorfer P (2019) Zur Spaltrissbildung von textilbewehrtem Beton. Dissertation, TU Wien

21. El Ghadioui R, Tran NL, Proske T et al. (2019) Cracking behaviour of carbon textile reinforced concrete members. In: Advances in engineering materials, structures and systems: Inovations, Mechanics and applications: Proceedings of the 7th international conference on structural engineering, mechanics and computation. CRC Press, Balkema, pp 1474-1479

22. König G, Tue NV (1996) Grundlagen und Bemessungshilfen für die Rißbreitenbeschränkung im Stahlbeton und Spannbeton. Deutscher Ausschuss für Stahlbeton, DAfStb Heft 466. Beuth Verlag, Berlin

23. Gerstle W, Ingraffea AR, Gergely P (1992) Tension stiffening: a fracture mechanics approach. In: Bond in Concrete: Proceedings of the international conference on bond in concrete. Rigg technical university, pp 97-106

24. Krips M (1985) Rißbreitenbeschränkung im Stahlbeton und Spannbeton. Mitteilungen aus dem Institut für Massivbau der Technischen Hochschule Darmstadt, Technische Hochschule Darmstadt

25. International Federation for Structural Concrete (1993) CEB-FIP Model Code 1990

26. Fischer A (1993) Modelluntersuchungen zur Ermittlung des Rißabstandes dicker Bauteile aus Stahlbeton. Dissertation, Technische Hochschule Darmstadt

27. DIN EN 1992-1-1/NA (2013) National Annex - Nationally determined parameters - Eurocode 2: Design of concrete structures - Part 1-1: General rules and rules for buildings; including Amendment A1 (2015)

28. Zink M (2000) Zum Biegeschubversagen schlanker Bauteile aus Hochleistungsbeton mit und ohne Vorspannung. Dissertation, Universität Leipzig

29. Reineck KH (1990) Ein mechanisches Modell für den Querkraftbereich von Stahlbetonbauten. Dissertation, Universität Stuttgart

30. Walraven JC (1980) Aggregate interlock: A theoretical and experimental analysis. Dissertation, Delft University of Technology

31. Baumann T, Rüsch H (1970) Schubversuche mit indirekter Krafteinleitung. Versuche zum Studium der Verdübelungswirkung der Biegezugbewehrung eines Stahlbetonbalkens. Ernst and Sohn, Berlin
32. Hegger J, Görtz S (2006) Querkraftmodell für Bauteile aus Normalbeton und Hochleistungsbeton. Beton- und Stahlbetonbau 101:695-705

33. Kani G (1964) The Riddle of Shear Failure and its Solution. J Am Concr Inst 61:441-467

34. Reissen K, Claßen M, Hegger J (2018) Shear in reinforced concrete slabs-experimental investigations in the effective shear width of one-way slabs under concentrated loads and with different degrees of rotational restraint. Struct Concr 19:36-48

35. Adam V, Hildebrand M, Hegger J (2019) Querkraftversuche mit Gleichstreckenlast an teileingespannten Stahlbetonplattenstreifen ohne Querkraftbewehrung. Bauingenieur 94:1-8

36. Kurth MC (2012) Zum Querkrafttragverhalten von Betonbauteilen mit Faserverbundkunststoff-Bewehrung. Dissertation, RWTH Aachen

37. Tureyen KA, Frosch RJ (2003) Concrete shear strength: another perspective. ACI Struct J 100(5):609-615

38. Tran NL (2018) Shear strength of slender reinforced concrete members without shear reinforcement. A mechanical model. Habilitation, TU Darmstadt

39. Tran NL (2017) A new shear model for fibre-reinforced concrete members without shear reinforcement. In: Hordijk, Lukovic (eds) Proceedings of the 2017 FIB symposium: high tech concrete: where technology and engineering meet, pp 727-739

40. Reineck KH, Kuchma DA, Fitik B (2012) Erweiterte Datenbanken zur Überprüfung der Querkraftbemessung für Konstruktionsbetonbauteile mit und ohne Bügel. Deutscher Ausschuss für Stahlbeton, DAfStb Heft 597. Beuth Verlag, Berlin

41. Massam L (2011) The behaviour of GFRP reinforced concrete beams in shear. Master Thesis, University of Toronto

42. Yost JR, Gross SP, Dinehart DW (2001) Shear strength of normal strength concrete beams reinforced with deformed GFRP bars. J Compos Constr 5:268-275

43. Tureyen AK, Frosch RJ (2002) Shear tests of FRP-reinforced concrete beams without stirrups. ACI Struct J 99:427-434

44. El-Sayed AK, El-Salakawy EF, Benmokrane B (2006) Shear capacity of high-strength concrete beams reinforced with FRP bars. ACI Struct J 103:383-389

45. El-Sayed AK, El-Salakawy EF, Benmokrane B (2006) Shear strength of FRP-reinforced concrete beams without transverse reinforcement. ACI Struct J 103:235-243

46. Guadagnini M, Pilakoutas K, Waldron P (2006) Shear resistance of FRP RC beams: experimental study. J Compos Constr 10:464-473

47. Niewels J (2008) Zum Tragverhalten von Betonbauteilen mit Faserverbundkunststoff-Bewehrung. Dissertation, RWTH Aachen

48. Bentz EC, Massam L, Collins MP (2010) Shear strength of large concrete members with FRP reinforcement. J Compos Constr 14:637-646

49. Razaqpur AG, Shedid M, Isgor B (2011) Shear strength of fiber-reinforced polymer reinforced concrete beams subject to unsymmetric loading. J Compos Constr 15:500-512

50. Alam MS, Hussein A (2012) Effect of member depth on shear strength of high-strength fiber-reinforced polymerreinforced concrete beams. J Compos Constr 16:119-126 
51. Alam MS, Hussein A (2013) Size effect on shear strength of FRP reinforced concrete beams without stirrups. J Compos Constr 17:507-516

52. Khaja MN, Sherwood EG (2013) Does the shear strength of reinforced concrete beams and slabs depend upon the flexural reinforcement ratio or the reinforcement strain? Can J Civ Eng 40:1068-1081

53. Matta F, El-Sayed AK, Nanni A et al (2013) Size effect on concrete shear strength in beams reinforced with fiber-reinforced polymer bars. ACI Struct J 110:617-628

54. Ali I, Abdul Samad AA, Mohamad N et al (2014) Evaluation of shear strength of concrete beams with GFRP reinforcement. Appl Mech Mater 660:603-612

55. Kom CH, Jang HS (2014) Concrete shear strength of normal and lightweight concrete beams reinforced with FRP bars. J Compos Constr 18:04013038-1-10

56. Bielak J, Adam V, Hegger J et al (2019) Shear capacity of textile-reinforced concrete slabs without shear reinforcement. Appl Sci 9:1382

57. Jumaa GB, Yousif AR (2019) Size effect in shear failure of high strength concrete beams without stirrup reinforced with basalt FRP bars. KSCE J Civ Eng 23:1636-1650

58. Hofmann S, Tran NL, Proske T et al. (2019) Shear capacity of BFRP reinforced concrete beams without shear reinforcement. In: Advances in engineering materials, structures and systems: Inovations, Mechanics and applications:
Proceedings of the 7th international conference on structural engineering, mechanics and computation. CRC Press, Balkema, pp 1531-1536

59. Cavagnis F (2017) Shear in reinforced concrete without transverse reinforcement: from refined experimental measurements to mechanical models. Dissertation, École Polytechnique Fédérale de Lausanne

60. Vecchio FJ, Collins MP (1986) The modified compressionfield theory for reinforced concrete element subjected to shear. ACI Struct J 83:219-231

61. Bažant ZP, Gambarova P (1980) Rough cracks in reinforced concrete. J Struct Div 106:819-842

62. Ulaga T (2003) Betonbauteile mit Stab- und Lamellenbewehrung: Verbund- und Zugmodellierung. Dissertation, Eidgenössische Technische Hochschule Zürich

63. Finsker J, Hagsten LG (2016) Mechanical model for the shear capacity of RC beams without stirrups: a proposal based on limit analysis. Eng Struct 115:220-231

64. Herbrand M, Hegger J (2017) Querkraftmodell für Bauteile ohne Schubbewehrung unter Druck- und Zugbeanspruchung. Beton- und Stahlbetonbau 112:704-713

Publisher's Note Springer Nature remains neutral with regard to jurisdictional claims in published maps and institutional affiliations. 